\title{
PENGARUH PROTEIN BIJI DURIAN (Durio zibethinus) YANG BERPERILAKU LEKTIN TERHADAP PERTUMBUHAN JAMUR Candida albicans
}

\section{THE INFLUENCE OF PROTEIN OF DURIAN SEEDS (Durio zibethinus) THAT BEHAVES LECTIN ON THE GROWTH OF Candida albicans FUNGUS}

\author{
Meirita Sari ${ }^{1)}$ \\ ${ }^{1)}$ Program Studi Teknologi Pertanian, Fakultas Pertanian, Universitas Dehasen \\ Email : meirita91@yahoo.com
}

\begin{abstract}
ABSTRAK
Penelitian ini merupakan salah satu bentuk pemanfaatan tumbuhan pangan, yaitu Durio Zibethinus. Senyawa lektin yang terkandung pada biji D. Zibethinus akan digunakan sebagai bahan antijamur. Penelitian ini meliputi isolasi lektin daun D. Zibethinus dengan menggunakan metode salting in dan salting out; penentuan konsentrasi lektin menggunakan metode biuret; dan pengujian aktivitas antijamur menggunakan metode difusi sumuran. Penelitian ini berguna bagi peneliti, masyarakat, bidang kesehatan, serta perkembangan ilmu pengetahuan maupun dunia pendidikan. Tujuan penelitian ini ialah untuk memperluas wawasan tentang pemanfaatan daun D. Zibethinus sebagai antijamur berbahan alam yang dapat menghambat pertumbuhan jamur. Oleh karena itu, penggunaan antijamur yang bersumber dari bahan alam dapat lebih dikembangkan di masa mendatang. Hasil penelitian menunjukkan adanya perbedaan yang signifikan pengaruh tiap variasi konsentrasi lektin terhadap luasnya Diameter Daya Hambat (DDH). Konsentrasi yang paling efektif untuk jamur C. albicans sebesar 100\% dengan kategori kekuatan antijamur tergolong kuat.Selain itu, informasi tentang lektin D. Zibethinus yang berfungsi sebagai antijamur dapat dijadikan bahan sumber belajar berupa modul dalam pembelajaran perkuliahan. Modul tersebut diharapkan dapat meningkatkan efisiensi dan efektivitas pembelajaran mahasiswa baik dari segi waktu, fasilitas maupun tenaga guna mencapai tujuan secara operasional.
\end{abstract}

Kata Kunci: Durio Zibethinus, Lektin, Antijamur, C. albicans,

\section{ABSTRACT}

The research is one form of the use of food plants, namely the Durio zibethinus $(D$. zibethinus). Lectin compounds that contained in D. zibethinus seeds. will be used as a antifungal agent. This research includes the lectins isolation of D. zibethinus leaves using salting in and salting out; determination of lectin concentration using the biuret method; and testing of antifungal activity using the well diffusion method. This research is useful for researchers, the public, health sector, and the development of science and the world of education. The purpose of this research was to expand insights on the use of D. zibethinus leaves as an antifungal agent based on nature that could inhibit fungal growth. Therefore, the use of antifungals sourced from natural materials can be further developed in the future. The results showed a significant difference in the effect of each variation of lectin concentration on the extent of inhibitory power diameter (IPD). The most effective concentration for $C$. albicans fungus was $100 \%$ grade, with the antifungal strength category classified as strong. In addition, information about D. zibethinus lectin which functions as an 
antifungal can be used as a learning resource in the form of modules in lecture learning. The module is expected to improve the efficiency and effectiveness of student learning both in terms of time, facilities and energy to achieve operational goals.

Keywords: Durio Zibethinus, Lectin, Antifungal, C. albicans

\section{PENDAHULUAN}

Kondisi geografis dan keadaan wilayah propinsi Bengkulu yang masih banyak hutan dimungkinkan banyak ditemukan berbagai jenis tumbuhan, salah satunya adalah durian (Durio Zibethinus). Durian adalah termasuk dalam suku Bombacaceae yang hanya terdapat di daerah tropis. Di indonesia durian merupakan buah yang sangat populer, bahkan diluar negeri terkenal dengan sebutan "The King of Fruits" atau "Raja Buah" namun biji durian memang belum memasyarakat untuk digunakan sebagai bahan makanan. Biji durian tersebut menjadi salah satu limbah yang terbengkalai atau tidak dimanfaatkan, yang sebenarnya banyak mengandung nilai tambah.

Tanaman ini diduga berpotensi sebagai tanaman obat, karena biji durian memiliki kandungan berupa protein yang belum dieksplorasi manfaatnya. Pada tiap 100 gram biji durian terdapat protein sebesar 2,6 gram pada biji segar dan 1,5 gram pada biji yang telah dimasak. Secara umum, protein pada tumbuhan telah diketahui memiliki peran penting dalam mencegah pertumbuhan mikroba atau sebagai protein antimikroba (Mahayasih, 2013). Jenis protein yang dapat berfungsi sebagai protein antimikroba salah satunya adalah lektin. Dimana pada tumbuhan diketahui kandungan lektin paling banyak terdapat pada biji daripada bagian tumbuhan yang lain (Sharon, 2004).

Istilah lektin berasal dari bahasa Yunani, yaitu legere yang berarti memilih. Lektin merupakan salah satu biomolekul yang bersifat anti nutrisi bagi metabolisme tubuh manusia. Lektin merupakan kelompok protein yang berinteraksi secara khas dengan karbohidrat yang spesifik. Lektin mempunyai sifat mengaglutinasi sel darah merah, oleh sebab itu dikenal juga sebagai hemaglutinin (Alroy, 1988). Lektin termasuk bagian sistem kekebalan tubuh dengan kemampuan sebagai antijamur dan anti inflamasi. Adanya sifat biologis yang dimiliki lektin, maka lektin berpotensi untuk dieksploitasi sebagai antitumor, imunomodulator, mitogenik, antiserangga, antijamur, dan antibakteri (Lin, 2008).

Pada saat ini, penyakit kulit akibat jamur merupakan penyakit kulit 
yang sering muncul di tengah masyarakat Indonesia. Jamur merupakan salah satu mikroorganisme penyebab penyakit infeksi pada masyarakat terutama di negara-negara tropis termasuk Indonesia. Iklim tropis dengan kelembapan udara yang tinggi di Indonesia sangat mendukung pertumbuhan jamur. Beberapa jenis jamur yang sering di temui dalam kehidupan sehari-hari seperti Candida albicans,

Penyakit infeksi pada manusia yang disebabkan oleh jamur di Indonesia masih relatif tinggi dan obat antijamur relatif lebih sedikit dibandingkan dengan antibakteri, oleh karena itu perlu dilakukan pengembangan (Pranoto, 2012). Pengobatan terhadap penyakit infeksi oleh jamur dapat menggunakan antijamur berbahan kimia. Namun dapat menimbulkan resistensi dan efek samping, karena itu perlu dilakukan penelitian mengenai antijamur berbahan alami dari biji Durio Zibethinus. Kemudahan memperoleh ekstrak dari Durio Zibethinus menjadi salah satu faktor pendukung dalam penelitian ini.

\section{METODE PENELITIAN}

\section{Alat}

Autoklaf, Refrigerated Sentrifuge, Laminary Air Flow, Spectrofotometer,
Magnetic Stirrer, Hotplate, Waterbath, Cawan Petri, Batang sebar, jarum ose, Erlenmeyer, Tabung Ukur, Tabung Reaksi, Rak Tabung Reaksi, Pipet Ukur, Gelas kimia, Labu ukur, suntikan eppendorf, inkubator.

\section{Bahan}

Biji durian Durio Zibethinus, Wrap, Microtube, Spuit (Needle+syringe) 5 cc, Spuit (Needle+syringe) $1 \mathrm{cc}$, Aluminum foil, Nutrient Broth(NB), Potato Dextrosa Agar (PDA), Plastik tebal, Reagen Biuret, Buffer tris $\mathrm{HCl}$, Akuades, Ammonium sulfat, Biakan jamur Candida albicans

\section{Prosedur Penelitian}

\section{a.Isolasi lektin biji durian}

Tahapan ini meliputi isolasi lektin yang dilanjutkan dengan perhitungan konsentrasi lektin. Adapun tahapannya sebagai berikut: sampel biji durian yang telah dipilih diambil sebanyak $40 \mathrm{~g}$ dibilas dan ditiriskan. Kemudian digiling hingga menjadi bubur serta dihomogenisasikan dalam $10 \mathrm{ml}$ larutan buffer tris $\mathrm{HCl} \mathrm{pH} 10$ (metode salting in) dalam kondisi lingkungan dingin. Homogenat disaring, cairan hasil saringan disentrifugasi dengan kecepatan $3500 \mathrm{rpm}$ selama 15 menit dengan $\mathrm{T}=$ $4^{\circ} \mathrm{C}$. Pellet Hasil sentrifugasi tahap 
pertama dibuang dan supernatan diambil.

Supernatan dipresipitasi dengan ammonium sulfat jenuh $70 \%$ (metode salting out) dengan perbandingan jumlah 1:1. Kemudian dilakukan sentrifugasi tahap kedua dengan kecepatan $13.500 \mathrm{rpm}$ selama 30 menit dengan $\mathrm{T}=4^{\circ} \mathrm{C}$. Pellet hasil sentrifugasi tahap kedua diambil, dan ditentukan konsentrasi proteinnya dengan metode biuret menggunakan spektrofotometer PD 303S. Sebanyak 0,5 mL sampel ditambahkan dengan 9,5 $\mathrm{mL}$ larutan biuret, divortex mixer, kemudian diletakkan pada penangas air (water bath) dengan suhu $40^{\circ} \mathrm{C}$ selama 10 menit. Setelah itu dilakukan pengukuran pada spektofotometer PD 303S dengan panjang gelombang $540 \mathrm{~nm}$ (Sari, 2015).

\section{b.Penentuan konsentrasi lektin}

Penentuan konsentrasi protein dengan metode biuret menggunakan spektrofotometer PD 303S. Larutan sampel yang akan diukur konsentrasinya diberi perlakuan sebagai berikut: $0,5 \mathrm{~mL}$ sampel ditambahkan dengan 9,5 mL larutan biuret, divortex mixer, kemudian diletakkan pada penangas air (water bath) dengan suhu $40^{\circ} \mathrm{C}$ selama 10 menit. Setelah itu dilakukan pengukuran pada spektofotometer PD 303S dengan panjang gelombang $540 \mathrm{~nm}$.

\section{c.Uji aktivitas antijamur}

Tahapan ini meliputi sterilisasi pembuatan media agar, alat dan bahan, peremajaan jamur, uji aktivitas antijamur serta perhitungan zona hambat. Adapun tahapannya sebagai berikut: Untuk pembuatan Media Potato Dextrose Agar (PDA) ditimbang Sebanyak 4 gram media PDA dimasukkan kedalam labu Erlenmeyer pyrex $250 \mathrm{ml}$, ditambahkan aquades hingga $100 \mathrm{ml}$. Sedangkan untuk NB (Nutrien Broth), ditimbang sebanyak 0,5 gram serbuk NB (Nutrien Broth) dimasukkan kedalam labu Erlenmeyer $250 \mathrm{ml}$, kemudian dilarutkan dengan akuades sampai volume $50 \mathrm{ml}$. kemudian kedua jenis larutan tersebut dipanaskan di atas hot plate sambil diaduk menggunakan magnetic stirrer hingga homogen.Selanjutnya alat dan bahan yang digunakan harus disterilkan terlebih dahulu agar terhindar dari kontaminasi. Proses sterilisasi menggunakan autoklaf dengan suhu $127^{\circ} \mathrm{C}$ selama 30 menit dilanjutkan penyinaran UV di dalam laminary air flow.

Sebelum memulai pengujian, jamur diremajakan terlebih dahulu dengan menggunakan media agar miring PDA pada suhu $37^{0} \mathrm{C}$ selama 24 jam. Dari biakan jamur pada agar miring diambil satu ose jamur dan dicampurkan kedalam $50 \mathrm{~mL}$ media NB sebagai suspensi jamur kemudian diaduk dengan 
menggunakan magnetic stirrer selama \pm 24 jam. Suspensi jamur dalam media NB yang berubah menjadi keruh dibandingkan kondisi awal, diukur OD (Optical Density) 0,6 dengan panjang gelombang $580 \mathrm{~nm}$.

Selanjutnya media cair tersebut dicampurkan ke dalam PDA, yaitu sebanyak $100 \mathrm{ml}$ PDA ditambahkan dengan $2 \mathrm{ml}$ biakan jamur yang berada di dalam media NB. Kemudian dituangkan ke dalam cawan petri sebanyak $20 \mathrm{ml}$ tiap cawan. Dibuat lubang/sumuran media agar pada cawan petri yang telah mengeras dengan diameter $6 \mathrm{~mm}$. Sampel uji yang digunakan yaitu lektin dengan 3 variasi konsentrasi, aquades sebagai kontrol negatif dan ketoconazole 900 ppm sebagai kontrol positif. Pada tiap sumuran diteteskan sampel uji sebanyak 10 micron menggunkan mikropipet eppendorf. Kemudian diinkubasi dengan suhu $37^{\circ} \mathrm{C}$ selama 24 jam. Setelah itu dilakukan penghitungan diameter daya hambat dikurangi dengan diameter sumuran $(6 \mathrm{~mm})$. Penghitungan zona hambat dilakukan tiga kali pada sudut pandang yang berbeda (Sari, 2015).

\section{d.Teknik Pengumpulan Dan Analisis} Data

Teknik pengumpulan data dilakukan dengan mengukur diameter daya hambat hasil uji aktivitas antijamur.

Teknik analisa data menggunakan analisa one way Anova apabila terdapat perbedaan yang nyata antar perlakuan dilanjutkan dengan uji Duncan Multiple Range Test

\section{HASIL DAN PEMBAHASAN}

\section{Isolasi protein}

Tumbuhan yang diisolasi proteinnya adalah tumbuhan Durio Zibethinus tepatnya pada bagian buah tumbuhan tersebut. Ada beberapa tahapan untuk mengekstraksi protein yaitu: (1) Penghalusan/memperluas permukaan sampel, (2) penghilangan pengotor protein, (3) pemisahan protein. Sebelum mengekstraksi protein, perlu dilakukan persiapan awal yaitu sampel harus dihaluskan terlebih dahulu, fungsi penghalusan ini untuk memperluas permukaan bidang sentuh sampel, sehingga kontak antara sampel dengan pelarut semakin banyak dan mempermudah penetrasi pelarut ke dalam sampel sehingga hasil semakin sempurna. Selain itu juga dimaksudkan agar sel atau jaringan tumbuhan yang mengandung senyawa-senyawa organik dapat terlarut sebanyak mungkin dalam pelarut yang terbatas.

Sampel yang telah halus, dihomogenkan dengan larutan buffer 
dingin Tris- $\mathrm{HCl} \mathrm{pH}$ 7,4. Larutan buffer dengan $\mathrm{pH}$ yang lebih rendah dari 7,4 akan mengkibatkan depurifikasi dan mengakibatkan protein terdistribusi ke fase fenol selama proses deproteinisasi. Sedangkan $\mathrm{pH}$ larutan yang lebih tinggi dari 7,4 akan mengakibatkan pemisahan untaian protein. Fungsi larutan buffer adalah untuk menjaga struktur protein selama proses penghancuran dan purifikasi sehingga memudahkan dalam mencegah aktivitas enzim pendegradasi protein dan mencegah perubahan pada molekul protein.

\section{Hasil homogenasi yang} dinamakan homogenat biasanya masih berupa larutan keruh yang terdiri dari debris sel (bagian sel yang tidak hancur), organel-organel sel dan makromolekul penyusun sel diantaranya yaitu protein. Untuk memisahkan molekul dalam larutan ini yaitu menggunakan metode sentrifugasi. Tujuan dari sentrifugasi yaitu pemisahan larutan berdasarkan perbedaan berat molekulnya. Dengan sentrifugasi, debris dan organel sel akan mengendap di dasar tabung sentrifus (dinamakan pellet), sedangkan makromolekul (termasuk di dalamnya protein) yang ukurannya jauh lebih kecil daripada debris dan organel sel tidak akan mengendap tetapi terlarut dalam buffer (dinamakan supernatan yang bening). Homogenat di masukkan dalam microtube ukuran $2 \mathrm{~mL}$, lalu disentrifugasi pada kecepatan 4500 rotation per minutes (rpm) selama 15 menit, sehingga supernatan dan pellet akan terpisah. Supernatan inilah yang dipakai sebagai sampel untuk analisis isolasi protein.

Supernatan hasil sentrifugasi pada tahap pertama perlu diendapkan kembali untuk mendapatkan ekstrak protein. Pengendapan dilakukan dengan menambahkan amonium sulfat $70 \%$. Supernatan yang dipresipitasi dengan ammonium sulfat $70 \%$ merupakan metode salting out. Mekanisme dasar salting out sangat kompleks tetapi dapat diperkirakan bahwa pengendapan terjadi karena persaingan antara garam dan protein untuk mengikat air. Pada konsentrasi tinggi, kekuatan ionik garam semakin kuat sehingga garam lebih dapat mengikat molekul air. Dengan demikian, tidak cukup banyak air yang terikat pada protein sehingga gaya tarik menarik antar molekul protein lebih menonjol dibandingkan dengan tarik menarik antara air dan protein. Dalam kondisi seperti itu protein akan mengendap.

Selama proses salting out berjalan, sangat penting untuk menjaga konsentrasi garam agar tidak menurun 
dalam larutan sehingga tidak terjadi

dilakukan pengadukan selama pengendapan yang bersamaan antara penambahan garam dalam prosedur protein yang ingin dimurnikan dengan salting out. Pada proses ini harus tetap protein yang tidak diinginkan (protein pencemar). Dengan demikian selalu dijaga kondisi suhu agar protein tidak terdenaturasi.

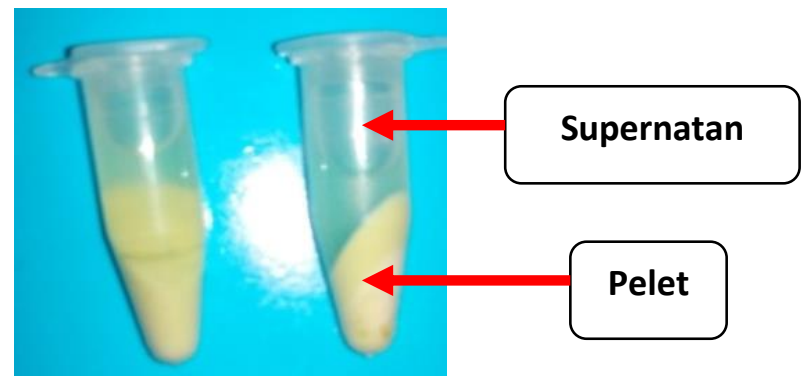

Gambar 1. Hasil sentrifugasi tahap pertama

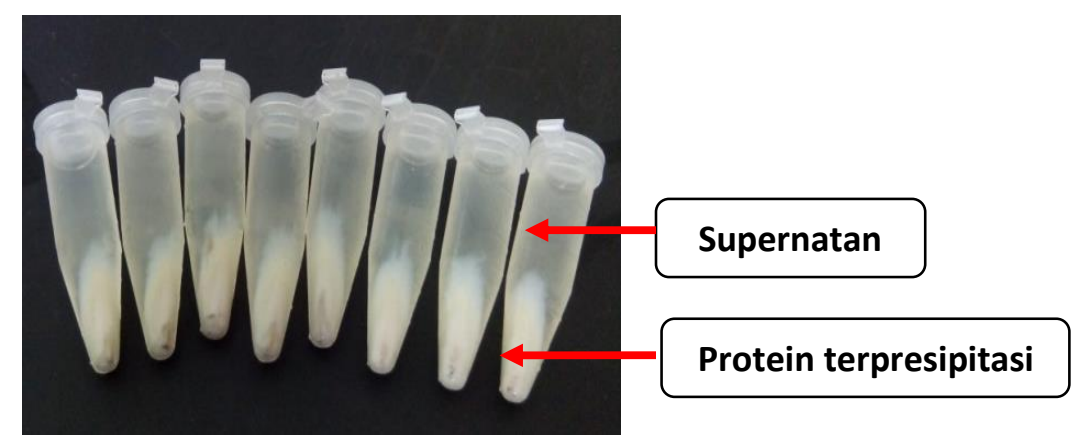

Gambar 2. Hasil sentrifugasi tahap kedua

Selanjutnya disentrifugasi pada kecepatan 13.500 rpm selama 30 menit untuk memisahkan protein terpresipitasi dengan larutannya (Sari, 2015), pelletnya diambil karena merupakan protein terpresipitasi, kemudian pellet tersebut dilakukan penentuan konsentrasi protein.

\section{Uji aktivitas antijamur}

Uji aktivitas antijamur yang dilakukan adalah uji secara kuantitatif dimana sampel yang digunakan adalah lektin biji Durio Zibethinus dengan variasi konsentrasi 100\%, 75\%, 50\%, $25 \%$. Pengujian aktivitas antijamur ini dilakukan secara In vitro dengan menggunakan jamur yang dikembangkan (inokulasi) dengan menggunakan media agar. Adapun media yang digunakan 
adalah Potato Dextrose Agar (PDA) sebagai media padat yang berfungsi dalam subkultur jamur dan media inokulasi jamur serta Nutrient Broth (NB) sebagai media cair yang berfungsi dalam suspensi peremajaan jamur.

Metode yang digunakan uji aktivitas antijamur yaitu metode sumuran/lubang. Metode ini merupakan salah satu dari metode difusi dalam uji aktivitas antijamur. Metode ini dilakukan dengan pembuatan lubang pada agar padat yang telah diinokulasi dengan jamur yang selanjutnya diisi dengan lektin sebagai sampel yang akan diuji. Setelah diinkubasi pada $\mathrm{T}=37{ }^{\mathrm{O}} \mathrm{C}$ selama 24 jam, pertumbuhan jamur diamati untuk melihat ada tidaknya daerah/zona hambat disekeliling lubang.

Pengukuran diameter daya hambat (DDH) dilakukan dengan 3 macam sudut pandang yang berbeda pada tiap sumur. Hasil penelitian menunjukkan adanya daerah hambat disekitar lubang pada tiap konsentrasi lektin. Sedangkan pada kontrol negatif yaitu Buffer Tris $\mathrm{HCl} \mathrm{pH}$ 7,4 tidak memberikan daerah hambat. Hal tersebut membuktikan bahwa pelarut tidak berpengaruh terhadap aktivitas antijamur, sehingga aktivitas hanya berasal dari larutan uji dan bukan dari pelarut yang dipakai. Buffer Tris $\mathrm{HCl} \quad \mathrm{pH} \quad 7,4$ digunakan sebagai kontrol negatif dengan tujuan untuk melarutkan protein yang terlarut pada biji Durio Zibethinussekaligus untuk menjaga kestabilan protein. Pada kontrol positif menggunakan antibiotik ketokonazol 15 $\mathrm{mg} / \mathrm{mL}$ sebagai pembanding.

Semakin tinggi konsentrasi lektin biji Durio Zibethinusyang digunakan maka semakin besar pula DDH yang dihasilkan, yang berarti semakin besar pula daerah yang bebas dari pertumbuhan jamur. Hasil DDH yang diperoleh akan dianalisis menggunakan One Way Anova. Berikut hasil analisis statistik tiap jenis jamur yang digunakan dalam penelitian ini. Hasil pengukuran zona hambat yang terbentuk dari lektin biji Durio Zibethinus terhadap jamur $C$. albicans dapat dilihat pada Tabel 1 .

Pada Tabel 1 dapat dilihat bahwa rerata zona hambat lektin biji $D$. Zibethinus terhadap pertumbuhan jamur C. albicans yang dihasilkan di sekeliling sumuran berbeda kekuatan daya hambatnya berdasarkan ketentuan Davis Stout pada tiap perlakuan konsentrasi. Mulai dari konsentrasi 25\% menghasilkan 5,2 $\mathrm{mm}$ dikategorikan sedang, 50\% menghasilkan $6,5 \mathrm{~mm}$ dikategorikan sedang, $75 \%$ menghasilkan 9,5 mm dikategorikan sedang, $100 \%$ menghasilkan $11 \mathrm{~mm}$ dikategorikan kuat. 


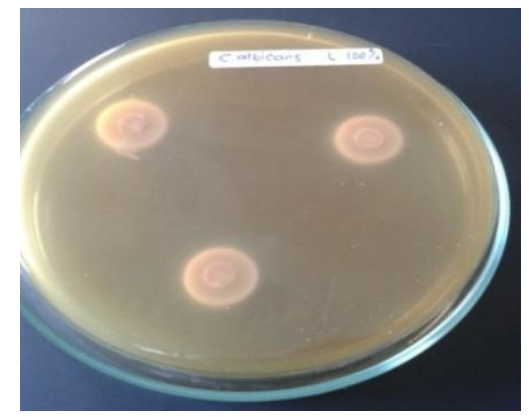

Gambar 3. Pembentukan DDH C. Albicans

Tabel 1. Pengamatan DDH jamur C. albicans

\begin{tabular}{|l|l|l|l|l|}
\hline No & $\begin{array}{l}\text { Konsentrasi protein } \\
(\mathbf{m g} / \mathrm{L})\end{array}$ & $\mathbf{N}$ & $\begin{array}{l}\text { Daya hambat } \\
(\mathbf{m m}) \\
\mathbf{X} \pm \mathbf{S D}\end{array}$ & $\begin{array}{l}\text { Kategori daya } \\
\text { hambat }\end{array}$ \\
\hline 1 & $25 \%$ & 3 & $5,2 \pm 0,30$ & Sedang \\
\hline 2 & $50 \%$ & 3 & $6,5 \pm 0,13$ & Sedang \\
\hline 3 & $75 \%$ & 3 & $9,5 \pm 0,20$ & Sedang \\
\hline 4 & $100 \%$ & 3 & $11 \pm 0,13$ & Kuat \\
\hline 5 & K+(Ketokonazol) & 3 & $24,0 \pm 0,20$ & Sangat kuat \\
\hline
\end{tabular}

Berdasarkan hasil uji One Way Anova menunjukkan nilai signifikansi ( $\mathrm{p}$ $=0,00)<0,05$ artinya perlakuan konsentrasi lektin biji D. Zibethinus mempunyai pengaruh yang signifikan atau bermakna terhadap pertumbuhan $C$. albicans. Hasil analisis diperoleh nilai $\mathrm{F}$ hitung yaitu 160.283 , sedangkan $\mathrm{F}$ tabel yaitu 3.21 pada taraf signifikan 0,05. Didapatkan bahwa F hitung lebih besar dari F tabel $(160.283>3.21)$, maka dapat disimpulkan bahwa hipotesis diterima pada taraf $95 \%$ yang artinya kesalahan tidak lebih dari 5\%. Hal ini menunjukkan bahwa empat konsentrasi $100 \%, 75 \%$, 50\%, 25\% lektin biji D. Zibethinus memberikan kemampuan aktivitas yang menghambat pertumbuhan jamur $C$. albicans. Hal ini menunjukkan setiap pemberian variasi konsentrasi lektin biji D. Zibethinus memiliki perbedaan yang nyata, sehingga perlu adanya uji lanjut yaitu post hoc test untuk mengetahui perlakuan atau konsentrasi manakah terdapat perbedaan daya hambat yang bermakna secara statistik.

Uji lanjutan yang dilakukan adalah uji duncan. Berdasarkan hasil uji Duncan bahwa pengaruh konsentrasi $25 \%$ sama dengan konsentrasi $50 \%$, dan pengaruh konsentrasi $50 \%$ sama dengan konsentrasi $75 \%$, kemudian pengaruh 
konsentrasi $75 \%$ sama dengan konsentrasi $100 \%$. Sehingga konsentrasi lektin yang efektif dalam menghambat $C$. albicans yaitu konsentrasi minimum dengan daya hambat besar, yaitu pada konsentrasi $100 \%$ dengan kategori kekuatan antijamur yang tergolong kuat.

Terbentuknya zona hambat dari keempat jenis jamur di atas menunjukkan bahwa lektin biji Durio Zibethinus mempunyai aktivitas sebagai antijamur. Dari hasil penelitian, menunjukkan bahwa terjadi peningkatan zona hambat seiring dengan meningkatnya konsentrasi lektin. Hal ini disebabkan semakin besar konsentrasi lektin yang terdapat dalam medium, maka jumlah lektin berdifusi ke dalam sel jamur semakin meningkat sehingga menyebabkan terganggunya pertumbuhan jamur. Septiadi (2013), menyatakan bahwa konsentrasi suatu bahan yang berfungsi sebagai antimikroba merupakan salah satu faktor penentu besar kecilnya kemampuan dalam menghambat pertumbuhan mikroba yang diuji.

Peneliti juga menduga adanya ikatan yang terbentuk antara lekin Durio Zibethinus dengan gugus karbohidrat spesifik pada membran sel jamur. Adanya reseptor pada membran sel jamur yang sesuai dengan lektin Durio
Zibethinus membentuk ikatan glikoprotein. Ikatan yang terbentuk ini mengakibatkan perubahan permeabilitasnya dan menimbulkan gangguan pada struktur dan fungsi membran sel. Membran sel berperan melindungi isi sel dan mengatur keluar masuknya molekul-molekul yang berguna untuk mempertahankan kehidupan sel (Alfiah, 2015). Perubahan permeabilitas membran sel menyebabkan enzim -enzim spesifik tidak dapat bekerja sehingga mengganggu metabolisme dan proses penyerapan nutrisi oleh jamur. Hal ini mengakibatkan sel jamur mengalami kekurangan nutrisi untuk proses pertumbuhan, sehingga lama-kelamaan membran sel akan mengalami lisis.

Obat sintesis ketokonazol digunakan sebagai kontrol positif, merupakan obat paten komersial, menunjukkan efek antijamur yang kuat terhadap jenis jamur yang diuji. Ketokonazol merupakan antibiotik turunan polien, yang dapat dikelompokkan pada gangguan di membran sel. Gangguan ini terjadi karena adanya ergosterol dalam sel jamur. Ergosterol merupakan komponen sterol yang sangat penting dan sangat mudah diserang oleh antibiotik turunan polien. Kompleks polien-ergosterol yang 
terjadi dapat membentuk suatu pori dan melalui pori tersebut konstituen essensial sel jamur seperti ion $\mathrm{K}$, fosfat anorganik, asam karboksilat, asam amino dan ester fosfat bocor keluar hingga menyebabkan kematian sel jamur. Penghambatan biosintesis ergosterol dalam sel jamur ini merupakan mekanisme yang disebabkan oleh senyawa turunan imidazol karena mampu menimbulkan ketidakteraturan membran sitoplasma jamur dengan cara mengubah permeabilitas membran dan mengubah fungsi membran dalam proses pengangkutan senyawa - senyawa essensial yang dapat menyebabkan ketidakseimbangan metabolik sehingga menghambat pertumbuhan atau menimbulkan kematian sel jamur (Siswandono 2000).

\section{KESIMPULAN}

Aktivitas lektin biji Durio Zibethinus sebagai antijamur melalui metode difusi rata-rata memberikan perbedaan daya hambat yang signifikan pada tiap perlakuan variasi konsentrasi. Konsentrasi lektin biji Durio Zibethinus yang paling efektif untuk jamur Candida albicans $100 \%$ dengan kategori kekuatan antijamur yang tergolong kuat.

\section{DAFTAR PUSTAKA}

Alfiah, R. R., Khotimah, S., Turnip, M. 2015. Efektivitas Ekstrak Metanol
Daun Sembung Rambat (Mikania micrantha Kunth) Terhadap Pertumbuhan Jamur Candida albicans. Jurnal Protobiont, Vol. 4(1): 52-57

Alroy, J., Ucci, AA., Perierra MEA. 1988. Lectin Histochemistry : an Update Advances in Immunohistochemistry. Ed.RA De Lellis, Raven Press NY; 93131

Lin. P, Xiujuan. Y, and TB Ng. 2008. Purification of melibiose-binding lectins from two cultivars of Chinese black soybeans. Acta Biochim Biophys Sin : 1029-1038

Mahayasih, P. G. M. W., T. Handoyo, and M. A. Hidayat. 2013. Antibacterial Activity of Water Soluble Protein from Porang Tubers (Amorphophallus muelleri Blume) Against Escherichia coli and Staphylococcus aureus. Jurnal Pustaka Kesehatan, Vol. 1 No.1

Pranoto.E.N, Farid ma'ruf. W, Pringgenies.D. 2012. Kajian Aktivitas Bioaktif ekstrak Teripang Pasir (Holothuria Scabra) terhadap jamur candida Albicans. Jurnal Pengolahan dan Bioteknologi Hasil Perikanan. Volume 1. No. 1, Hal.1-8

Sari, Meirita. 2015. Isolasi Lektin Biji Kabau (Archidendron microcarpum) dan uji aktivitas

Antibakteri serta implementasinya sebagai modul pembelajaran Koba. Jurnal PENDIPA. Vol 2. No. 3 Hal 10-16

Septiadi, T., Pringgenies, D., Radjasa, O. K. 2013. Uji Fitokimia dan Aktivitas Antijamur Ekstrak Teripang Keling (Holoturia atra) Dari Pantai Bandengan Jepara Terhadap Jamur Candida albicans. Journal of Marine Research, Vol. 2, No. 2, Hal. 7684 
Sharon N \& Lis H, 2004. History of lectin: From hemagglutinins to biological recognition molecules. Glycobiology, 14 (11): 58-59
Siswandono, Soekardjo. 2000. Kimia Medisinal. Surabaya: Airlangga Press 